\title{
VERBAL WARFARE IN THE POLISH MEDIA: AN ANALYSIS OF CONCEPTUAL METAPHORS IN POLITICAL DisCOURSE
}

\author{
EWA GIEROŃ-CZEPCZOR \\ PWSZ, Racibórz \\ ewa_g-cz@wp.pl
}

\begin{abstract}
"The use and abuse of language cannot be separated from each other."

Paul de Man (1978: 21)
\end{abstract}

\begin{abstract}
Cognitive semanticists, especially George Lakoff and the Rockridge Institute, joined the analysts of political discourse in the 1990s. Much has been said about the metaphorical language of the US leaders, Bush and Obama, especially during the time of the War on Terror, and a range of conceptual metaphors have been pinpointed, such as THE STATE AS A PERSON, THE STATE AS THE FAMILY, THE USA AS A MORAL LEADER/DEFENDER OF THE JUST CAUSE, WAR AS MEDICINE, ARGUMENT IS WAR. Polish political discourse is, in contrast, largely focused on internal issues and debates. The resulting image of the nation and its aims, as found in official and unofficial statements made by the Polish government and parliamentarians portrays a pervading simplistic and dualistic picture of the nation and - more importantly - suggests that all aspects of politics evoke the imagery of war waged against all other parties involved.

This study traces conceptual metaphors in a large corpus of material. The primary sources include interviews with politicians as well as texts written by journalists commenting on the Polish political scene and the latest developments. Another source is daily news on popular portals and online services of selected Polish dailies and magazines. All the materials cover a period between September 2011 and mid-January 2012.

The outcome of the analyses of spoken and written data reveals that political, social and economic antagonisms are well fed by language which highlights dichotomies and depicts 'the others' as the source of all evil. The metaphorical language largely follows the patterns investigated and described by Lakoff, providing a wealth of material to support the claim that ARGUMENT IS WAR. In the light of the collected data, multiple 'wars' are in progress successfully generating language of conflict.
\end{abstract}

\section{Introduction}

This article concentrates on the verbal interactions and commentaries by the representatives of two opposing parties on the Polish political scene: the ruling Civic Platform (Platforma Obywatelska) and the main opposition party called Law and Justice 
(Prawo i Sprawiedliwość). Descended from one common original post-communist rightist movement, both parties have been engaged in fierce debates revealing explicit and implicit hostile attitudes towards each other for the last several years.

This project focuses on metaphors understood as conceptual mappings structuring human thought and its product, language (Lakoff \& Johnson 1980, Lakoff 1987, Taylor 2003, Barcelona 2003). The material for the study exemplifies current Polish political discourse on the basis of interviews, news items and commentaries collected from popular Polish portals, online magazines and political blogs in the period between September 2011 (the final stage of the parliamentary election) and mid-January 2012.

The purpose of the study is to identify (1) the most popular metaphors which structure Polish political discourse currently, and (2) the preferred range of lexical exponents in respective source domains. The analysis has been inspired by repeatedly voiced concerns about the brutalisation of the Polish language of politics which perpetuates hostilities within the nation. The Media Ethics Council (Rada Etyki Mediów) keep guard over the standards of public debate to prevent and condemn abuse, manipulation and discrimination, yet to little effect so far. Nevertheless, conceptual metaphors are less easy to detect and react against, and these - superficially 'innocent' and harmless - are often the basis for the construction of negative models and the encouragement of enmity.

\section{Have principles disappeared?}

Instead of being a means of reaching a consensus or searching for solutions to problems, political discourse in Poland explicitly violates ethical canons and the cooperative principle alike.

Paweł Śpiewak, a sociologist, notes in Panel dyskusyjny "Język polskiej polityki po 1989 roku" (2009) that the language used on the Polish political scene is becoming "a tool for a merciless fight, for humiliating the opponent, for hurting him/her" [translation mine]. In the same discussion held by the Senate of the Polish Republic, Michat Głowiński, an expert on communist newspeak, claims that totalitarian discourse dominates Polish political debates just as it did 30 years ago, and the dichotomy "us vs. them" is its one notable feature. Ideological divisions between PO and PiS, the two largest Polish parties engaged in a perpetual war, are clearly-set, constantly highlighted, and strengthened by politicians and journalists. In the light of the hypothesis that language does - to a certain extent - shape the way we think such verbal conflict may be regarded as an alarming phenomenon: creating hostility and giving rise to further abuse.

\subsection{Vernacularisation of the language of the media in Poland}

One relevant factor with reference to the language and style represented by politicians and the media in Poland nowadays is "the modelling of public discourse upon the discursive practices of ordinary life, 'conversational' practices in a broad sense" (Fairclough, 1994: 253). Since 1989, which marked the onset of the post-communist era, the language of Polish politics has undergone significant changes in many respects. As 
Duszak (2006) aptly notes "(t)he desired direction of change was to make the language of politics more dialogic, direct, expressive and open." As a result, politicians go to any lengths to convince the electorate they are one of the people; this might be achieved by appearing in informal contexts and, most commonly, with the use of colloquial speech, clichés and new popular coinages, frequently buzz words. Utterances produced by politicians, however, tend to verge on insult, or might be interpreted as a veiled attack. The language is rich in traditional metaphors represented by a set of conventionalised phrases, as well as in less evident, yet effective language based on conceptual structures which shape political discourse in terms of a conflict rather than a constructive verbal exchange. The authors of Stownik polszczyzny politycznej po 1989 roku, Rafał Zimny and Pawel Nowak (2009) stress the importance of conceptual metaphors. Their recipients, mostly subconsciously, acquire and accept the view of reality they construct (ibid.: 326). As such, conceptual metaphors and the images and scripts they imply are potentially more dangerous than decorative rhetorical figures which direct attention to the form of the utterance rather than its content.

\subsection{Verbal directness of Poles}

Apart from political factors, one reason for this predilection for the vernacular in speech could be part of the cultural script. Wierzbicka (1991: 121) observes that "Polish culture values (...) uninhibited emotional expression." Pragmalinguistic analyses do confirm that Poles rarely apply hedging techniques, and this also refers to the ways in which opinions are voiced. Goddard \& Wierzbicka (1997) believe that in most contexts Polish culture is likely "to actively encourage 'directness' of expression" rather than to advocate means of toning messages down. Boski et al. (1999: 8) refer to previous crosscultural research and their own studies by claiming that "Polish scripts of interpersonal communication encourage spontaneity of affective expression, including negative moods and feelings."

\subsection{Mediatisation of politics}

According to Fetzer and Weizman (2006: 146) "politics has undergone dramatic changes and has become a media endeavor." The media are no longer subservient to politicians they have themselves begun to participate in politics by shaping public opinion (Oniszczuk 2011), or - more radically - can be seen as an autonomous and competitive source of power (Street, 2006: 197). In these circumstances, as Bralczyk (2009) notes, "(a) politician exists through language. Once he/she stops talking, he/she ceases to exist as a politician" [translation mine]. "The language of politics has been subjected to the media" (ibid.) and, consequently, 'new orality' (Duszak 2006) based on simple talk prevails in political discourse. In order to reach, and 'seduce' wide audiences of voters, politicians apply indiscriminate, vivid language, colloquial lexicon, analogies and clichés. One cannot help thinking that politician are expected to cater for lower tastes and appeal to the masses in the same way that celebrities do. 
Kamińska-Szmaj (2008: 263) sees another factor, apart from the involvement of politics in the mass media, as a source of competitiveness found in language. Following Magdoń (1995), she believes that Polish political propaganda is full of the 'spirit of play/of a game" ('duch zabawy') marked by its density of metaphors, as well as verbal and nonverbal forms of dramatisation.

More convincingly, Kloch (2010: 115) attributes the verbal aggression to the globalisation and Americanisation of the media under the guise of freedom of speech and effective journalism.

\section{Political discourse as a transfer of values}

Language is never neutral (Bakhtin 1981, 1984; Fairclough 1995) and political discourse is no exception:

(a) metaphorical utterance often conveys or instigates a mental or emotional attitude or a value judgment about the target subject matter. This is perhaps especially prevalent in metaphor used in political discourse. (Barnden 2008: 333)

The value of the Conceptual Metaphor Theory for the study of political discourse was stressed by Lakoff and Johnson (1980), its founding fathers, who saw a significant role of metaphorical mappings "in the construction of social and political reality" (ibid.: 156). More recently, Zinken, Hellsten and Nerlich (2008: 364), in their sociocultural study, stress the importance of the study of metaphor, with its ideological bias, in discourse. The axiological weight of metaphors cannot be overestimated: Gibbs (1994) distinguishes between linguistic metaphor as a product, and conceptual metaphor as a mental process; the former has the power of activating representations in the mind. These form complex structures which regulate categorization and normative thinking. With ideological discourse resting on binary oppositions, e.g. good vs. evil, moral vs. immoral, the bodily basis of conceptual mappings play an essential role in shaping and instilling values.

\section{Conceptual metaphors in the language of politicians and political commentators: material and theoretical constructs}

The analysis undertaken here is based on a corpus of 53 written texts ( 44 news items and political commentaries, and 9 entries in blogs run by politicians) and 55 transcripts of radio interviews. In the total of 108 texts, a significant number of 735 conceptual metaphors was attested. This should be considered to be a rough estimate as metaphor identification is to a large extent subject to individual interpretation, and as such is always vulnerable to criticism. Another weak point is the delimitation of domains (Langacker 1987) as noted in Feyaerts (1999). Nevertheless, this study might be considered as an overview of the phenomenon in question, an impulse for further investigation of conceptual phenomena in discourse analysis. 
The analysis of linguistic representations - with the application of the tenets of cognitive semantics - in search of conceptual representations which shape cultural discourse in Poland, might contribute to research on political manipulation. This is achieved through the influencing of conceptualization and cognition as a result of the repeated application of certain - more or less hidden - metaphors. In this respect, cognitive semantics is one research territory which complements pragmalinguistic discourse analysis of political language.

\subsection{Image schemas and conceptual structure}

The main tenet of cognitive linguistics is a close correlation between the concepts human beings form and the nature of our physical bodies. This correlation is better known as embodiment. According to this hypothesis, linguistic output (or lexical exponents) constitute the peak of the cognitive iceberg, the final product of the mind which is structured by more basic general representations. These include image schemas which derive from sensory and perceptual experience as we interact with the physical world. Graphically, the connection between language and its conceptual underpinnings can be represented as:

\section{LANGUAGE:}

lexical exponents and grammatical structures

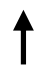

CONCEPTUAL STRUCTURE:

mental representations including image schemas

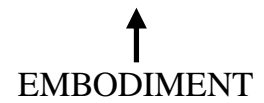

the body's interactions with the physical world

Embodied experience of space, force, containment etc. determines other concepts, including abstractions. All of these reflect the physicality of the human body and the positive or negative associations which result from its functioning in the environment.

Conceptual mapping is, in simple terms, understood as a mapping, or transfer, between diverse domains of experience. In order to convey an abstract meaning, a natural tendency is to draw from another area of experience (SOURCE DOMAIN), a concrete one. In political discourse, such a mental process - i.e. a mapping between a source and a target domain, can, for instance, be found in language which represents a political party as a person, e.g. SLD potrzebuje czasu (SLD needs time), Platforma nie jest bez grzechu (Platform is not without a sin), or "GPC" pokazuje prawdziwa twarz $P i S-u$ " (GPC shows the true face of PiS). Ontological correspondences are retained: since a party is a person, its members are organs, important members are the heart, a party in trouble suffers etc.: Myśmy byli samym sercem PiS (We were the very heart of PiS), Sojusz ciągle ma traumę (The Alliance still suffers from trauma), SLD nie jest zdrowa partia (SLD is not a healthy party). 


\subsection{Evaluative metaphors}

Association evoked by certain patterns of experience account for the presence of selected image schemas in evaluative contexts. These underlie three types of metaphors which are pervasive in speech: orientational, sensorimotor and visual metaphors.

Orientational metaphors in the material culled for the present study (accompanied with literal, word for word translations, which are intended to retain the original Polish elements of the respective source domains) include: GOOD IS UP; BAD IS DOWN; SUCCESS IS UP; FAILURE IS DOWN; HIGH STATUS IS UP; LOW STATUS IS DOWN. Further elaborations include:

- $\quad$ MORAL IS UP/IMMORAL IS DOWN:

(1) Kurski sięgnal bruku ... [25] (lit.) Kurski has hit the pavement ...

- $\quad$ POWER IS UP:

(2) ... jak Polska mogłaby wyglądać pod dobrymi (...) rządami. [31] ... what Poland might look like under good (...) leadership.

(3) Musimy schodzić bezpośrednio do ludzi. [59] We have to get down directly to people.

(4) Jak pan czyta te ruchy: Kopacz w górę, Schetyna w dól. [103] How do you read (=interpret) these moves: Kopacz up, Schetyna down.

- $\quad$ FAILURE IS DOWN:

(5) dziś jesteśmy na samym dnie. [102] ... today we are at the very bottom.

(6) ... nas już na samym początku próbuje się wdeptać w ziemię. [6]

... from the very beginning there have been attempts, to tread us into the ground.

Sensorimotor image-schematic metaphors attested in the corpus comprise: POSITIVE DEVELOPMENT IS STABILITY; STABILITY IS PHYSICAL BALANCE; STABILITY IS COMPLETENESS/INTEGRITY; STABILITY IS SOLIDITY:

- $\quad$ A POLITICAL PARTY IS A STRUCTURE

(7) Lewica to nie spójna partia, ale dramatycznie pęknięta formacja. [4] The Left is not a coherent party, but a dramatically fractured formation.

(8) to jest dużo większe pęknięcie niż po odejściu Kluzik-Rostkowskiej. [62] this is a much bigger fracture than the one following Kluzik Rostkowska's leaving.

- $\quad$ POLITICAL STABILITY IS BALANCE:

(9) zachwianie pozycji Jarosława Kaczyńskiego w tym ugrupowaniu. [7] the imbalance of Jaroslaw Kaczynski's position in this grouping.

(10) Nieco podniósł się z upadku Palikot ... [68] Palikot has slightly risen from his collapse ... 
Visual aspects of human interactions with the physical world result in the following assessment metaphors: GOOD IS BRIGHT; BAD IS DARK; ORIENTATION IS VISION. Further entailments include:

- $\quad$ DIRT IS BAD/DIRTY IS IMMORAL:

(12) MSW czyszczone z ludzi Schetyny. [41]

The Ministry of Home Affairs has been cleared of Schetyna's people.

- $\quad$ KNOWLEDGE IS LIGHT/IGNORANCE IS DARKNESS:

(13) muszę (...) zachować się wyjątkowo fair i wyjątkowo przejrzyście. Nie może być żadnego ściemniania, żadnych gier ... [83]

I have to act in an exceptionally fair and transparent way.

There must be no dirty tricks/smears (lit. making something dark).

(14) Żenujące kłamstwa ministra Boniego, który wciskal ludziom ciemnotę ... [79] The embarrassing lies of minister Boni, who shoved ignorance $(\approx$ Pol. 'darkness') down people's throats.

- INTELLIGENCE IS A LIGHT SOURCE:

(15) Ludzie często powtarzają: nikt pana nie zna. A ja pytam: kiedy miałem zabłysnąć? [16]

People keep saying: nobody knows you. And I ask: when was I to shine (lit. flash)?

\subsection{Ontological metaphors: containers}

The imagery of containers is pervasive in thought and language and structures various aspects of experience. In the context of political discourse, politics itself as well as its elements, e.g. parties, are understood in terms of containers, boxes, buildings and other structures:

- $\quad$ PARTIES ARE CONTAINERS (STRUCTURES/BUILDINGS etc.)

(16) Partie stają się takimi pojemnikami, które muszą pomieścić różne wizje państwa. [94]

Parties are becoming such containers, which have to accommodate diverse visions of the state.

(17) Młodzi bili głowami o szklany sufit, partia promowała wówczas starych działaczy. [16]

The young beat their heads against the glass ceiling, while the party was promoting the old activists.

(18) ... tylko wtedy można budować silną partię. [87]

... only then can you construct a strong party. 
- $\quad$ STABILITY IS COMPLETENESS/INTEGRITY

(19) To [= odejście posłów] już nie jest obkruszanie narożników, ale głębokie tąpnięcie. [62]

This [= MPs' leaving] is more than the edges/corners crumbling; it's a rockburst.

- $\quad$ POLITICS IS A CONTAINER/BOUNDED AREA

(20) ... ci, którzy żyją w świecie pozapolitycznym. [54]

... those who live in the extra-political world.

\subsection{Ontological metaphors: forces}

Politics is action and interaction, and - inevitably - requires force. This perception leads to modelling political activities in terms of physical forces (wind, vapour pressure, crushing, attracting). Consequently:

- $\quad$ INTENSITY OF ACTIVITY IS AMOUNT OF PHYSICAL ENERGY

(21) nawet Marta Kaczyńska już nie walczy tak ostro jak zaczynała [78] even Marta Kaczyńska is no longer fighting as fiercely as she did at first

(22) ... gdyby twardo wszedl do politycznej gry [4] $\ldots$ if he had entered the political game keenly (lit. 'hard')

(23) Moi dawni koledzy są rozczarowani i czekają. Pod pokrywką kipi. [12] My former colleagues are waiting disappointed. The situation is boiling up/seething under the lid.

(24) Gwiazda PO miażdży byłego szefa. [32]

The PO star crushes his former boss.

(25) Prezes jest teraz wyciszony. [17]

(26) The chairman has now been subdued (lit. quietened).

- A PROBLEM IS A FORCE, i.e. OBSTRUCTION, NATURAL FORCE, PHYSICAL OPPRESSION

(27) Mam wrażenie, że stoję ciągle przed murem zbudowanym $\mathbf{z}$ tych samych spraw. [81]

I have the impression I am up against a brick wall constructed of the same issues?

(28) Jeżeli przebijemy próg powyżej 5 proc, to wszystko jest w porządku. [77]

If we can get past (lit. cut through) the threshold of 5 percent everything will be $\mathrm{OK}$ ?

\section{Conceptual model of competition}

The model of competition, like any other purposeful activity, is conceptually structured as movement from one location (source) towards another (goal) along a path. Hence, any advancement, progress is expressed linguistically as: 
- $\quad$ PURPOSEFUL ACTIVITY IS TRAVELLING (ALONG A PATH TOWARD A DESTINATION)

(29) ... drogi polityków dawno się rozeszly. [78]

... those politicians parted their ways a long time ago.

(30) Mówił pan, że idzie do Sejmu po władzę. [103]

You said you were going (lit. walking) to the Sejm to take power.

(31) Tak jakby rząd się gdzieś zagubil. [68]

(32) As if the government has got lost somewhere.

(33) Ruch Palikota z pewnością go nie poprze, bo "nie tędy droga". [42]

Palikot's Movement will certainly not support him, because "this is not the way."

Consistent application of the PATH imagery, frequent in political discourse in numerous languages (Kövecses 2002), can be found in longer stretches of texts, as in:

(34) My posuwamy się w tempie, które uważamy za bezpieczne. Wprawdzie nie satysfakcjonuje ono tych, którzy chcą pędzić jak najszybciej, ale jednak kierunek jest ten sam. Prawdziwa polityczna alternatywa w Polsce jest dziś taka: albo krok po kroku będziemy spokojnie budować Europę w Polsce (...) albo utkniemy w okopach wzniesionych przez Jarosława Kaczyńskiego i jego partię. [83]

We are inching at a speed that we consider safe. Admittedly, this does not satisfy those who want to rush as fast as possible, yet the direction is the same. A true political alternative for Poland today is as follows: we will either build Europe in Poland step by step (...) or we will get stuck in the trenches dug (lit. 'built') by Jaroslaw Kaczyński and his party.

Any problem encountered on the PATH is an obstacle, as in (26) and (27) above.

- A PURPOSEFUL ACTIVITY IS A COMPETITIVE ACTIVITY (INDIVIDUAL or in TEAMS)

Political activity is commonly presented as endeavour requiring special skills, and, not infrequently, putting 'the player' at risk. Most commonly, scenarios and elements of a race, boxing match, card game, hunting, gymnastics or ball game are utilized:

(35) Prawdą jednak jest, że przy wielkich ambicjach Napieralskiego i lewicy pojawiały się pomysły, że to oni będą rozdawać karty. [56]

It's true, however, that with the great ambitions of Napieralski and the left, there were hopes that they would be dealing the cards.

(36) Dowgielewicz: Karty mieliśmy słabe, ale udało się osiągnąć cel. [52] Dowgielewicz: We had weak cards but we did manage to achieve the goal.

(37) Wiem, że to jest gra. Oni w taki sposób się ustawiają, żeby wygrać a potem robić swoje. [105]

I know it's a game: They position themselves so they can win and do their own thing later. 
(38) Jeśli premier wypadnie dobrze, wejdzie do europejskiej superligi. [94]

If the Prime Minister is successful, he'll enter the European Super League.

(39) Palikot, mistrz wolt. [70]

Palikot, a master of vaulting.

(40) Jeżeli [Kaczyński] po raz kolejny zostanie wypunktowany przez Tuska i odesłany do narożnika [43]

If [Kaczyński] is once again counted off by Tusk and sent to the corner ...

(41) Donald Tusk na politycznym ringu boksuje całkiem nieźle. [43]

Donald Tusk throws a fairly decent punch in the political ring.

(42) A kto wygra wyścig Palikot-Miller? [56]

And who's going to win the Palikot vs. Miller race?

(43) Kibicowal Schetynie? [102]

Did he cheer Schetyna on?

(44) [o Tusku] Lekcję zapamiętał i biega głównie po tej prawej stronie boiska, tylko z rzadka zapędzając się do środka. [94]

[of Tusk] He remembers the lesson and runs mainly on the right side of the pitch, only rarely rushing towards the centre.

(45) Ale w drugiej połowie dekady obaj wylądowali poza głównym ringiem. [43]

But in the second half of the decade they both landed outside the main ring.

The imagery of a boxing match, a brutal one-on-one fight, appears to reflect the top political 'duels' best:

(46) Wieloletnia walka Tuska z braćmi Kaczyńskimi była prawdziwą próbą charakteru, twardości i to jak na razie - po pierwszych rundach przegranych walką wygraną. Stał się zawodnikiem bezsprzecznie w pełni zawodowym, który może nie dysponuje jakimś potężnym ciosem, ale za to sam jest nań odporny, może pochwalić się wysoką techniką, szybkością i pracą nóg. Umie też faulować, zwłaszcza gdy sędzia nie widzi. Jest elegancki, ale też potrafi zacwaniaczyć. Nie da się bezkarnie opukać, zwłaszcza że pracuje nad kondycją i nie wydaje się zmęczony. Wie, że Kaczyński czyha na jeden cios, chce zwyciężyć przez nokaut albo liczy na to, że pod rywalem zapadnie się ring. Dlatego Tusk musi uważać na przeciwnika, ring i sekundantów jednocześnie. [43]

Tusk's perennial fight against the Kaczyński brothers was a true test of character, and stamina, which so far - after the first lost rounds -has been won. He has undisputably become a fully professional contestant, who might not have a powerful blow (at his disposal), yet is resistant to ones himself, can boast about his technique, speed and footwork. He also knows how to foul,especially when the judge can't see. He's elegant, but also able to play things smart. He can't be 'knocked' with impunity; with all his hard work to keep in shape, he doesn't seem to be tired. Kaczyński lies in wait for a single blow, wanting to win with a knockout punch, or hopes the ring will collapse beneath his rival. That's why Tusk has to watch out for his opponent, the ring and the seconds all at the same time. 
POLITICAL PARTIES ARE TEAMS

(47) Wdarł się do Sejmu, mimo że w jego drużynie nie było politycznych gwiazd. [70]

He got into the Parliament even though there were no political stars on his team?

(48) Startując od zera, można wejść do parlamentu ze sporą reprezentacją. [88]

Starting from nothing, one might get into parliament with a decent team.

- INDIVIDUAL POLITICIANS ARE (professional) PLAYERS

(49) Transfery[polityków] $\mathrm{z}$ prawa, a zwłaszcza $\mathrm{z}$ lewa, miały umacniać to wrażenie [7]

Those transfers [of politicians] from the right, and even more so from the left, were to reinforce the impression ...

- $\quad \ldots$ or WEAPONS/TOOLS:

(50) Donald Tusk gra Millerem, by dusić Waldemara Pawlaka [12]

Donald Tusk is playing with Miller (instr.) $=$ uses Miller to strangle Waldemar Pawlak ...

Citation (48) represents an instance of a complex mapping: the Prime Minister uses one of the government's staunch opponents (as a tool) in order to intimidate, literally 'strangle' the coalition party leader. A proper interpretation requires reference to several underlying domains involved in a conceptual integration process.

\subsection{A one-on-one physical aggression}

As implied above, a purposeful activity can take the form of a combat, e.g. a boxing fight. The following citations illustrate this aspect of political competition vividly:

(51) Poręba bije w Tuska. Premier odpowiada, a Barroso się śmieje. [20] Poręba hits Tusk. The Prime Minister responds, and Barroso laughs.

(52) Donald Tusk, Jarosław Kaczyński. Ostatni taki pojedynek. [43] Donald Tusk, Jaroslaw Kaczyński. The last such duel.

(53) W Poznaniu starli się Waldy Dzikowski z PO (...) oraz Tadeusz Dziuba z PiS. [32]

In Poznan Waldy Dzikowski (PO) clashed with Tadeusz Dziuba (PiS).

(54) Kandydat Platformy rozłożył na lopatki kontrkandydatów. [32] Platform's candidate knocked his counter candidates into a cocked hat (lit. 'laid them on their shoulder blades')

\subsection{POLITICS IS WAR (plus entailments)}

The target domain of POLITICAL COMPETITION is understood in terms of the source domain, WAR. As the corpus material clearly suggests, ubiquitous lexical exponents in 
Polish political discourse include nouns and nominal phrases better suited for military contexts, such as: armia (army), kapitulacja (surrender), bitwa (battle), front (front), defensywa (defensive), okopy (trenches), broń (weapon), pobojowisko (battlefield), pojedynek (duel), klęska (defeat), strategia (strategy), nalot (air raid, swoop), pole manewru (room for manoeuvre), and tykajaca bomba (time bomb). Most frequently attested verbs comprise: atakować (to attack), walczyć (to fight), pacyfikować (to suppress),and ścierać się (to clash). A range of collocational phrases, such as: toczyć wojnę/wojenkę (to wage war/war + diminutive suffix), walka na śmierć $i$ życie (mortal combat), przelewać krew (to shed blood), zwierać szeregi (to draw up in battle array), and wytracić komuś z ręki bron' (to cut the ground from under sb's feet) add to the mercilessness of the activities on the political scene.

Selected citations illustrate the ferocity of political competition as presented in the Polish media today:

(57) Tusk rozkłada sily, pozycjonuje armię. [104]

Tusk is setting out his forces, positioning the army.

(58) utkniemy w okopach wzniesionych przez Jarosława Kaczyńskiego i jego partię. [83]

we'll get stuck in the trenches constructed by J. Kaczynski and his party.

(59) lewicę najbardziej interesuje walka - Millera z Kaliszem, Millera z Palikotem. [102]

The Left is mostly interested in fighting - Miller vs. Kalisz, Miller vs. Palikot.

(60) No z tej walki może wyjść wielkie pobojowisko i zgliszcza.

Well, this fight might end up with a vast wreck and charred remains.

(61) obie armie politycznego sporu w Polsce mają podobne sily. I nikt nie ma szans wygrać tej wojny, co najwyżej bitwę albo dwie. [54]

both armies in this political dispute have similar forces. And neither stands a chance of winning this war; a battle or two at the most.

(62) SLD zwarla szeregi i ruszyła do ofensywy. [4]

SLD have closed ranks and gone onto the offensive.

(63) Palikot obstawia flankę lewicowo-liberalną, a Gowin - konserwatywną. [11]

Palikot guards the left-liberal flank, while Gowin - the conservative one.

(64) Państwo zaczęło przegrywać z Kościołem w drugiej połowie lat 80. XX w. [84]

The state started to lose against the Church in the second half of the 1980s.

(65) Kaczyński (...) już tylko broni swojego terytorium ... [56]

Kaczynski (...) is only defending his territory now ... 
(66) Jestem człowiekiem, który przelal najwięcej krwi dla tej partii. [101]

He is the man who has spilled the most blood for his party.

(67) Polityka (...) to już tylko pole walki. Nie do pierwszej krwi, lecz do ostatniej. [54]

Politics (...) is solely a battlefield. Not till the first (sight of) blood but to the last ('until the bitter end').

By analogy, PARTIES ARE MILITARY ORGANISATIONS:

(68) PiS i PO to dwie armie, które się okopały [108]

$\mathrm{PiS}$ and PO are two armies which have dug in (the trenches)...

(69) Tusk mobilizuje partię. [71]

Tusk is mobilising his party.

(70) Kaczyński może tylko raz w miesiącu pojawiać się w tym miejscu, by zagrzewać swych żołnierzy do walki [78]

Kaczyński can turn up in this place once a month only to rouse (lit. warm) his soldiers to fight

(71) prezesa będzie otaczał coraz mniejszy krąg pretorianów. [43] the chairman will be surrounded by a dwindling Praetorian Guard.

(72) wszystkie hufce Kaczyńskiego ... [78]

all Kaczynski's regiments ...

(73) Słychać doniesienia, że liczy szable i sam może opuścić PiS ... [3]

There are rumours that he is counting sabres and might leave PiS himself ...

(74) robimy (...) nowy zaciąg w elektoracie. [11]

We are having a new enlistment of the electorate.

WORDS ARE WEAPONS in the dog-eat-dog world of politics:

(75) Janusz Palikot w bardzo ostrych słowach ocenia zachowanie rzecznika rządu [44]

Palikot judges the behaviour of the government spokesperson with very sharp words

(76) To nie są żadne debaty, ale walki na słowa, przepychanki. [2]

These are no debates but word fights, jostling.

(77) Dyskusja zmienia się w wymianę chwytów retorycznych. [2]

The discussion turns into an exchange of rhetorical figures (lit. ploys; grabs).

Worse still, OFFENSIVE WORDS ARE EXCREMENT which can be use as a weapon by political opponents:

(78) chłopaka, który na stronie "antykomor" zabawiał się rzucaniem gównem w prezydenta. [17]

a boy who amused himself on the 'anti-Komor' page by throwing shit at the President. 
Attributing features of certain animals to party leaders and members highlights either positive or negative features. Source domains abound in a range of species, such as: moles, dinosaurs, young wolves, thus suggesting that POLITICIANS ARE ANIMALS:

(79) Przed podjęciem każdej decyzji będzie musiał pielgrzymować do lewicowych dinozaurów. [4]

Before he makes any decision, he'll have to go on a pilgrimage to the left-wing dinosaurs.

(80) SLD ze swoim młodym szefem i grupą wilczków o nieznanych nazwiskach [4] SLD with its new boss and a group of young wolves with unknown surnames

(81) To (...) wyrzucenie "gada" i dwóch "płazów" jak prezes mówi o Ziobrze, Kurskim i Cymańskim ... [98]

This (...) expulsion of the 'reptile' and two 'amphibians' - as the chairman refers to Ziobro, Kurski and Cymanski ...

(82) Dzisiejsza lewica jest formacją wielkich samców alfa. [4]

Today's Left is a formation of big alfa males.

This mapping is less explicit with lexical exponents like: stado (herd), gniazdo (nest), matecznik (den/lair; backwoods) or hodować (to breed):

(83) pomysł, żeby wyhodować sobie Palikota. [31]

the idea to breed Palikot for himself.

(84) Tusk mości sobie wygodne gniazdo do rządzenia [103]

Tusk is getting his comfortable nest (ready) for his rule.

War requires physical strength, hence the success of the (STRONG) PEOPLE ARE MACHINES metaphor:

Starcia "lokomotyw". W stolicy doszło do starcia liderów największych partii. [32]

The clashes of the '(railway) engines. In the capital the leaders of the biggest parties have clashed.

The imagery of war resembling medieval battles which pervades political discourse is further extended onto politicians. POLITICAL LEADERS ARE RULERS/KINGS metaphors add to this wider picture:

(86) ... ktoś musiałby powiedzieć szefowi [tzn. Kaczyńskiemu], że się myli. Ale każdy, kto tak mówi, podważa majestat władcy. [62]

Someone would have to tell the boss (i.e. Kaczynski) that he is wrong. But anyone who says so, calls the ruler's authority into question.

Endowed with authority and special powers politicians are (demi-)gods:

... dla wyznawców Kaczyńskiego ... [93]

... for the believers in Kaczyński ... 
Citations (53)-(85) exemplify a mere fraction of war metaphors and their entailments found in the corpus of texts analysed here. Yet, a coherent picture of consistent patterns in mappings between the source domain (WAR) and the target domain (POLITICS) is evident. For Polish readers and listeners this language is by no means unfamiliar. The selection of citations above comes from popular sources and the choice of words is characteristic of the regular register. Politics as a brutal activity is part of formal and informal registers alike; the distinction is, nevertheless, blurred in the mediatisation of politics.

\section{3 'Star Wars' in Polish politics?}

A more complex mental process, in fact, a blend of mappings transfers political conflicts onto space:

(89) Zachowujecie się, jakbyście przylecieli z planety PiS. [20]

You behave as if you have come from the PiS planet.

(90) Minister powrócił jak kometa. Odgrzanym kotletem. [30]

The minister has come back like a comet. On a reheated cutlet.

Citations (86) and (87) reflect the IMPORTANCE IS CENTRALITY metaphor, also found in:

(91) włączyć Polskę do jądra decyzyjnego Unii Europejskiej [73]

to build Poland into the decision-making nucleus of the EU

(92) spychając na margines ludzi, (którzy dobrze czuli się w PRL) [7] pushing the people (who felt good in communist Poland) off onto the margins?

trzon wyborców, a zwłaszcza aktywistów [7]

the hard core of constituents, especially the activists

Polska może być peryferią, zmarginalizowana [73]

Poland might become a periphery, become marginalised,

as well as the mapping: SHARING BELIEFS IS PROXIMITY, also attested in:

(95) Najważniejsze jest to, że jesteśmy z premierem w dalszym ciągu blisko [56]

The most important thing is that we are still close to the Prime Minister

(96) Na drugim biegunie znajduje się PiS [26]

$\mathrm{PiS}$ is situated on the opposite pole.

From the anthropocentric perspective, objects in space are remote, of little importance, and so are the people conceived of as aliens: weird, maladjusted to the reality of the human world, potentially dangerous. Citation (87) adds the IDEAS ARE FOOD mapping to this extraterrestrial scenario: a reheated cutlet stands for an idea which is no 
longer fresh and appealing, yet in this context is used a sort of 'vehicle' for political purposes.

\subsection{All's fair in love and war}

Analogies between war and love have been drawn for ages and pervade today's political discourse in Poland. POLITICAL ACTIVITY IS SEXUAL ACTIVITY/MARITAL RELATIONSHIP mappings - with honeymoons, flirts, and break-offs on the level of semantics - are fairly common and recurrent:

(97) Janusz Palikot nie jest dziewicą polityczną [6] Janusz Palikot isn't a political virgin

(98) Radio Maryja i "Gazeta Polska" dopieszczają twardych zwolenników PiS-u [17]

Radio Maryja and Gazeta Polska are fondling the staunch (lit. 'hard', 'tough') followers of PiS.

(99) jak bardzo PO chce podbić serca zamiastowych [46] how much PO wants to win (lit. to conquer!) the hearts of the country folk

(100) Donald Tusk i Grzegorz Schetyna - związek, który ostatnio przechodzi ostry kryzys. [71]

Donald Tusk and Grzegorz Schetyna - a relationship which is undergoing a rough crisis.

(101) Przestrzegałbym SLD przed padaniem w ramiona Palikota [96] I would warn SLD against falling into Palikot's arms.

(102) Czyli romanse $z$ Palikotem i SLD będziecie traktowali jak zdradę, a zdrada oznacza koniec malżeństwa? [104]

Will you then consider the affairs between Palikot and SLD as infidelity, and infidelity as the end of the marriage?

As was the case with a range of other metaphors, the complexity of (94) - (99) involves a cultural component. The script for POLITICAL ACTIVITY IS SEXUAL ACTIVITY/MARITAL RELATIONSHIP requires a knowledge of the values attributed to human relationships shared by Polish speakers.

\subsection{Other metaphorical mappings}

Apart from the conceptual metaphors and their elaborations described in section 5.1 5.4 a wide range of other common mappings has been exhibited in the material under analysis. The most typical ones (illustrated with the most frequent lexical exponents in brackets) include:

\section{A POLITICAL PARTY/ORGANISATION IS A PERSON}

(body, illness, death)

A POLITICAL PARTY IS A MACHINERY

(machine, apparatus, wear out, failure) 
THE STATE IS A PERSON

(this sick state, failing an exam, protecting its citizens)

POLITICIANS ARE ACTORS

(political scene, an interrupted performance, electorate $=$ extras)

POLITICIANS ARE MUSICIANS

(playing 3 pianos: PSL, SLD and Palikot)

POLITICAL PARTIES ARE VEHICLES/SHIPS

(drowning the party, pushed out, to take the helm)

POWER IS A (DESIRED) OBJECT

(to trust somebody with leadership)

POLITICAL OPPONENTS ARE ROGUES

(Platform heisted the media)

IMPORTANCE IS CENTRALITY

(on the margins, the hard core, gather around the leader)

POLITICS IS FLOWING WATER

(the currents of political life)

CHANGES ARE MOVEMENTS

(a creeping totalitarian state)

ACTIVE IS ALIVE/INACTIVE IS DEAD

(political cemeteries, shiftless opposition)

POLITICAL ACTIVITY IS A COMMERCIAL ACTIVITY

(demand for radical policy, buying ideas, the Polish government as an 'advertising agency')

ANGER IS HEAT/STORM/ELECTRIC CHARGE

(suspense= Pol. voltage; sparking between A and B).

These and others beyond the scope of this study also deserve the attention of linguists, discourse analysts, and anyone who is aware of the fact that "cognitive semantics and axiology are closely related" (Cortés de los Ríos, 2002: 39).

\section{Conclusions}

The corpus of 108 texts which has been investigated with the aim of identifying the conceptual metaphors which structure political discourse in Poland would suggest a number of conclusions:

a. metaphorical conceptual mappings are ubiquitous, and along with metonymies (intra-domain mappings) result in a range of concepts which vary in their degree of complexity (frequently understood and interpreted against a domain matrix which involves the awareness of cultural scripts);

b. metonymy is as significant as metaphor and in many cases these two processes work together to activate a meaning of high specifity;

c. metaphors of war definitely constitute an overwhelming majority in the sample of data, frequently building on primary metaphors which exhibit evaluative functions;

d. less common concepts of politics draw upon the domains of ARTS, COMMERCE/BUSINESS, and JOURNEY/VOYAGE; 
e. unlike American discourse in the realm of politics, Polish hardly ever resorts to FAMILY metaphors; the LEADER IS A FATHER metaphor appears merely once, and even this single instance is highly controversial as the implication of cannibalism might be taken into consideration if the polysemy of the verb 'consume' is taken into consideration:

(103) [Tusk] stał się ojcem zwycięstwa i skonsumowal je [56]

Tusk became the father of this victory and ate (!) it.

Occasionally, voters might be treated like children, as in (101), yet it is the aspect of innocence or naivety that is highlighted in the context, rather than family ties:

Kaczyński nuci kołysankę wyborcy PO [17]

Kaczyński hums a lullaby to the PO voter.

f. The implications which have arisen in the current study would seem to situate Polish political discourse within what Tannen (1998) calls the Argument Culture (1998). The conceptual and linguistic "tendency to approach every problem as if it were a fight between two sides" is undoubtedly richly illustrated in political discourse in the Polish media. "We see it in headlines that are always using metaphors for war. It's a general atmosphere of animosity and contention that has taken over our public discourse" (ibid.).

\section{References}

Bakhtin, Michail (1981). "Discourse in the novel". In Holquist, M. (Ed.) The Dialogic Imagination: four essays by Bakhtin, $M$. Austin: University of Texas Press.

Bakhtin, Michail (1984). Problems of Dostoevsky's Poetics, Manchester: Manchester University Press.

Barnden, John A. (2008). "Metaphor and Artificial Intelligence. Why They Matter to Each Other". In Raymond W. Gibbs (Ed.), The Cambridge Handbook of Metaphor and Thought (311-338). Cambridge: CUP.

Boski, Pawel, Fons Van de Vijver, Helena Hurme \& Jolanta Miluska (1999). "Perception and Evaluation of Polish Cultural Femininity in Poland, the United States, Finland, and the Netherlands". Cross-Cultural Research, May 1999 33, 131161, doi:10.1177/106939719903300201

Bralczyk: to media kształtują język polityków (2009). Gazeta Prawna [online]. Retrieved from

http://www.gazetaprawna.pl/wiadomosci/artykuly/365077,bralczyk_to_media_ksztal tuja_jezyk_politykow.html

Cortés de los Ríos, Enriqueta (2002). "Cognitive Semantics and Axiology: A New Proposal to Study Metaphor in Economics Advertising Discourse". Revista Alicantina de Estudios Ingleses 15 (2000), 39-47. Universidad de Alicante. 
Duszak, Anna (2006). "Why 'New' Newspeak? Axiological Insights into Language Ideologies and Practices in Poland". In C. Mar-Molinero \& P. Stevenson (Eds.), Language Ideologies, Policies and Practices: Language and the Future of Europe (91-103). Houndmills \& New York: Palgrave Macmillan.

Gibbs, Raymond W. (1994). The Poetics of Mind: Figurative Thought, Language, and Understanding. Cambridge: CUP.

Goddard, Cliff \& Anna Wierzbicka (1997). Discourse and Culture. In T. A. van Dijk (Ed.), Discourse as Social Interaction (231-259). London: Sage Publications.

Fairclough, Norman (1994). "Conversationalization of Public Discourse and the Authority of the Consumer." In R. Keat, N. Whiteley \& N. Abercrombie (Eds.), The Authority of the Consumer (253-268). London: Routledge.

Fairclough, Norman (1995). Critical Discourse Analysis. London: Longman.

Fetzer, Anita \& Elda Weizman (2006). "Political Discourse as Mediated and Public Discourse". Journal of Pragmatics 38, 143-153.

Feyaerts, Kurt (1999). "Metonymic hierarchies. The conceptualization of stupidity in German idiomatic expressions". In K.-U. Panther \& G. Radden, Metonymy in Language and Thought (309-332). Amsterdam/Philadelphia: John Benjamins.

Kamińska-Szmaj, Irena (2008). "Język polityki na tle przemian kulturowych". Acta Universitatis Wratislaviensis, no. 3060, Język a kultura, tom 20, 253-265. Wrocław: Uniwersytet Wrocławski.

Kloch, Zbigniew (2010). Agresja i kłótnie w mediach a potoczne zachowania językowe. Nauka 2/2010, pp.113-128. Polska Akademia Nauk. http://www.portalwiedzy.pan.pl/images/stories/pliki/publikacje/nauka/2010/02/N-22010-9-Kloch.pdf

Kövecses, Z. (2002) Metaphor. A Practical Introduction. Oxford/New York: Oxford University Press.

Lakoff, George (1987). Women, Fire, and Dangerous Things. What Categories Reveal about the Mind. Chicago and London: University of Chicago Press.

Lakoff, George \& Mark Johnson (1980). Metaphors We Live By. Chicago: University of Chicago Press.

Langacker, Ronald W. (1987). Foundations of Cognitive Grammar. Volume I: Theoretical Prerequisites. Stanford, CA: Stanford University Press.

Magdoń, Andrzej (1995). Duch zabawy w mediach. Zeszyty Prasoznawcze no 3-4, 7 16.

Oniszczuk, Zbigniew (2011). "Mediatyzacja polityki i polityzacja mediów. Dwa wymiary wzajemnych relacji”. Studia Medioznawcze, no 4 (47), 11-22. Warszawa: Instytut Dziennikarstwa Uniwersytetu Warszawskiego.

Panel dyskusyjny "Język polskiej polityki po 1989 roku" (2009, October 27). Senat RP. Wydarzenia. Retrieved from http://ww2.senat.pl/k7/agenda/wydarz/2009/091027.htm

Street, John (2006). Mass media, polityka, demokracja. Kraków: Wydawnictwo Uniwersytetu Jagiellońskiego.

Tannen, Deborah (1998, March 27). The Argument Culture. The NewsHour with Jim Lehrer Transcript. Retrieved from http://www.pbs.org/newshour/gergen/march98/tannen_3-27.html 
Wierzbicka, Anna (1991). Cross-Cultural Pragmatics. Berlin/New York: Mouton de Gruyter.

Zimny, Rafał \& Paweł Nowak (2009). Stownik polszczyzny politycznej po 1989 roku. Warszawa: Wydawnictwo Naukowe PWN.

Zinken, Jörg, Iina Hellsten \& Brigitte Nerlich (2008). "Discourse metaphors". In R. Dirven, R. Frank, T. Ziemke \& J. Zlatev (Eds.), Body, Language, and Mind. Vol. 2. Sociocultural Situatedness (363-385). Berlin: Mouton.

\section{Materials Analysed:}

[1] Szostkiewicz, Adam (2010, July 30). Czym się karmi polska polityka? Polskie geny polityczne. Polityka.pl. Retrieved from http://www.polityka.pl/kraj/

analizy/1507670,1,czym-sie-karmi-polska-polityka.read

[2] Hołówka, Teresa (2011, September 22). Polska debata - nielogiczna, niebezpieczna. Argument słomianej kukly. $\quad$ Polityka.pl. Retrieved from http://www.polityka.pl/kraj/wywiady/1519384,2,polska-debata---nielogicznaniebezpieczna.read\#ixzz1lPOTRMp3

[3] Gociek, Piotr \& Piotr Gursztyn (2011, October 18). Nikt w tej chwili nie ma zamiaru usuwać Ziobry. Rp.pl, Wiadomości, Wydarzenia dnia. Retrieved from http://www.rp.pl/artykul/107684,735274.html

[4] Krasowski, Robert (2011, March 25). Buty Kwaśniewskiego. Polityka.pl. Retrieved from http://www.polityka.pl/kraj/analizy/1513936,2,sld---partia-na-glinianych-

nogach.read\#ixzz11Po4WS6v

[5] Kamińska, Agnieszka \& Julia Pitera (2012, January 24). Chaos w sprawie ACTA miał wystraszyć rząd. Polskieradio.pl, Trójka, Salon polityczny Trójki. Retrieved from http://www.polskieradio.pl/9/299/Artykul/523037,Chaos-w-sprawie-ACTA-mial-wystraszyc-rzad

[6] Olczyk Eliza \& Wanda Nowicka (2011, October 12). Chcą nam przyprawić gębę. Rp.pl. Retrieved from http://www.rp.pl/artykul/731930.html?p=2

[7] Władyka, Wiesław \& Aleksander Hall (2011, October). Dobrze się nam wydarzyło. Polityka.pl. Retrieved from http://www.polityka.pl/kraj/wywiady/

1520254,1,rozmowa-z-aleksandrem-hallem-ministrem-w-rzadzie-mazowieckiego.read

[8] Donald przeczołguje PSL. Ludzie PSL wylecą z TVP? (2012, January 11). Wprost.pl. Retrieved from http://www.wprost.pl/ar/287507/Donald-przeczolguje-PSL-Ludzie-PSL-wyleca-zTVP

[9] Hofman, Adam (2012, January 12). Jeżeli Kaczyński strzela sobie w kolano, to Donald Tusk odgryza sobie rękę i nogę. Onet.pl. Retrieved from http://wiadomosci.

onet.pl/kraj/jezeli-kaczynski-strzela-sobie-w-kolano-to-donald-, 1,5003523

[10] Wittenberg, Anna (2012, January 16). Filozofia Tuska - sięganie do kieszeni pacjentów. Polskieradio.pl, Salon polityczny Trójki. Retrieved from http://www.polskieradio.pl/9/299/Artykul/518048,Filozofia-Tuska-sieganie-do-kieszeni-pacjentow [11] Janicki, Mariusz \& Wiesław Władyka (2010, September 17). Dlaczego dajemy się oszukiwać politykom? Gra w ciemnego Luda. Retrieved from http://www.polityka.pl/kraj/analizy/1508554,1,dlaczego-dajemy-sie-oszukiwac-

politykom.read?backTo=http://www.polityka.pl/kraj/wywiady/1518622,1,ekspert-ocenia-jakpartie-wypadaja-w-internecie.read\#ixzz1 y4r9sKOU

[12] Palikot: PO jest spacyfikowana przez Tuska. Moi dawni koledzy są rozczarowani. (2012, January 13). Onet. Wiadomości. Excerpts from a radio interview by TOK.fm. Retrieved from http://wiadomosci.onet.pl/kraj/palikot-po-jest-spacyfikowana-przez-tuska-moidawn,1,4996872, wiadomosc.html 
[13] Jacek Kurski: muszę stanąć w obronie PO. (2012, January 15). Onet. Wiadomości. Excerpts from an interview by Radio Zet. Retrieved from: http://wiadomosci.onet.pl/kraj/jacek-kurskimusze-stanac-w-obronie-po, 1,4998414, wiadomosc.html

[14] Trzeciak, Sergiusz \& Malwina Dziedzic (2011, August 17). Ekspert ocenia, jak partie wypadają w internecie. PiS - 5, PO - 4, SLD - 3+. Retrieved from Więcej pod adresem http://www.polityka.pl/kraj/wywiady/1518622,1,ekspert-ocenia-jak-partie-wypadaja-w-

internecie.read\#ixzz1lPWe5ug6

[15] Palikot, Janusz (2012, January 31). Jaka jest cena za siedzenie przy stole? Palikot.blog.onet.pl. Retrieved from http://wiadomosci.onet.pl/blogi/jaka-jest-cena-za-siedzenieprzy-stole,4690500,450779180,blog.html

[16] Starowieyska, Magda (2011, October 12). Janusz Palikot i jego drużyna. Rp.pl. Retrieved from http://www.rp.pl/artykul/731543-Janusz-Palikot--i-jego-druzyna.html

[17] Nowakowska, Agata (2011, September 28). Kaczyński nuci kołysankę wyborcy PO. Gazeta wyborcza.pl. Retrieved from http://ad.adview.pl/ad/reloadwww?dir=/wyborcza/\&jsp=

$23 \& \mathrm{dx}=105405 \& \mathrm{typ}=101 \& \mathrm{nr}=1 \& \mathrm{mb}=1 \& \mathrm{t}=1326999109866$

[18] Osiecki, Grzegorz (2011, November 19). Kaczyńskiego czeka ciężka walka... Wirtualnapolska.pl. Retrieved from http://wiadomosci.wp.pl/title,Kaczynskiego-czeka-ciezkawalka,wid,13969370, wiadomosc.html

[19] Senyszyn, Jonnna \& Jacek Nizinkiewicz (2011, December 9). Senyszyn: Kandyduję, żeby zmienić oblicze partii. Tej partii. Onet.pl. Retrieved from http://wiadomosci.onet.pl/tylko-wonecie/senyszyn-kandyduje-zeby-zmienic-oblicze-partii-tej,1,4961793, wiadomosc.html

[20] Kłótnia polsko-polska w euro parlamencie. (2011, December 14). Dziennik.pl. Retrieved from http://wiadomosci.dziennik.pl/polityka/artykuly/371007,polska-prezydencja-w-unii-europejskiej-

donald-tusk-podsumowal-prezydencje.html

[21] Strony Sejmu, prezydenta i rządowe przestały działać. Kolejny atak hakerów 'za' ACTA? (2012, January 21). M.wyborcza.pl. Retrieved from http://m.wyborcza.pl/

wyborcza/1,105226,11006028,Strony_Sejmu_prezydenta_i_rzadowe_przestaly_dzialac.html [22] Zieliński, Jarosław (2012, January 11). Konflikt prokuratur to walka na śmierć i życie. TOK FM, wp.pl. Retrieved from http://wiadomosci.wp.pl/kat,131636,

title,Konflikt-prokuratur-to-walka-na-smierc-i-zycie,wid,14155496,wiadomosc.html?

ticaid=1ea75

[23] Jaryczewski, Artur (2012, January 19). Konflikt prokuratur: prezydent nie jest notariuszem. Salon polityczny Trójki. Polskieradio.pl. Retrieved from http://www.polskieradio.pl/9/299/Artykul/520234,Konflikt-prokuratur-prezydent-nie-jestnotariuszem

[24] Michalski, Cezary (2012, January 23). TV Trwam na multipleksie, czyli kopanie się z Rydzykiem. Newsweek.pl. Retrieved from http://polska.newsweek.pl/tv-trwam-na-multipleksie-czyli-kopanie-sie-z-rydzykiem, $87472,1,1 . \mathrm{html}$

[25] Mastalerek, Marcin (2011, November 30). Poseł PiS: Kurski sięgnął bruku, przekroczył Rubikon. Blogi polityczne w Onecie. Retrieved from http://wiadomosci.onet.pl/kraj/posel-piskurski-siegnal-bruku-przekroczyl-rubikon,1,4938081, wiadomosc.html

[26] Olczyk, Eliza \& Wojciech Wybranowski (2012, January 13). Lewica w związku partnerskim. Rp.pl. Retrieved from http://www.rp.pl/artykul/16,791022-Lewica-w-zwiazku-partnerskim.html

[27] Kamiński, Michał Tomasz (2011, July 6). Na kogo pracują europosłowie PiS? Onet.blog. Retrieved from http://michaltomaszkaminski.blog.onet.pl

[28] Boni, Michał \& Anna Wittenberg (2012, January 26). Michał Boni o ACTA: dostaliśmy burę. Polskieradio.pl, Salon polityczny Trójki. Retrieved from http://www.polskieradio.pl/9/299/Artykul/525135,Michal-Boni-o-ACTA-dostalismy-bure

[29] Miller, Leszek \& Marcin Zaborski (2011, December 12). Miller: kto myśli tak samo, ten nie myśli zbyt wiele. Polskieradio.pl. Retrieved from http://www.polskieradio.pl/9/1279/Artykul/497704,Miller-kto-mysli-tak-samo -ten-nie-mysli-zbyt-wiele 
[30] Siwiec, Marek (2012, January 13). Siwiec na blogu: Minister powrócił jak kometa. Odgrzanym kotletem. Blogi polityczne $w$ Onecie. Retrieved from $\mathrm{http} / / /$ wiadomosci.onet.pl/kraj/siwiec-na-blogu-minister-powrocil-jak-kometa-

odgrz, 1,4997098, wiadomosc.html

[31]Hofman, Adam \& Jacek Nizinkiewicz (2012, January 19). "Na stanowisko premiera Tusk szykuje Ewę Kopacz". Onet.pl. Retrieved from http://wiadomosci.onet.pl/tylko-w-onecie/nastanowisko-premiera-tusk-szykuje-ewe-kopacz,1,5002131,wiadomosc.html

[32] Najostrzejsze pojedynki (2011, October 10). Galerie. Wiadomosci.wp.pl. Retrieved from http://wiadomosci.wp.pl/gid,13878939,title,Najostrzejsze-pojedynki,wid,14156076,galeria.html [32]

[33] Borkowska, Grażyna (2012, January 19). Komu nie zależy na niani. M.wyborcza.pl. Retrieved from http://m.wyborcza.pl/wyborcza/1,105405,10991623,

Komu_nie_zalezy_na_niani.html

[34] Gadzinowski, Piotr (2011). Nie bójmy się imigrantów. Przegląd (online version), no.40/2011, p. 45). Retrieved from http://www.przeglad-tygodnik.pl/pl/artykul/nie-bojmy-sie-imigrantow.

[35] Kurski: nie dziwię się, że Tuska obnoszą za to w lektyce. (2011, December 15). Wiadomosci.onet.pl. Retrieved from http://wiadomosci.onet.pl/kraj/kurski-nie-dziwie-sie-ze-tuskaobnosza-za-to-w-lek, 1,4967396,wiadomosc.html

[36] Hofman, Adam (2011, December 14). Hofman: nie jestem jak policja, potrafię liczyć. Gość Radia Zet. Retrieved from http://wiadomosci.onet.pl/kraj/hofman-nie-jestem-jak-policja-potrafieliczyc, 1,4966290, wiadomosc.html

[37] Olejnik, Monika \& Elżbieta Jakubiak (2011, November 15). Niech Kaczyński i Ziobro wybiorą Jakubiak. Kropka nad ' $i$ '. Retrieved from http://www.tvn24.pl/12690,1724389,0,1,jakubiak-nie-popiera-ani-ziobry-ani-

kaczynskiego,wiadomosc.html

[38] Raczkowski, Grzegorz \& Andrzej Zoll (2011, October 15). Nieobywatelscy. Polityka.pl. Retrieved from http://www.polityka.pl/kraj/1520454,1,rozmowa-prof-andrzej-zoll-o-polsce-powyborach.read\#ixzz1lPF9s7s4

[39] O marszu. (2011, November 9). Niepodlegli.net. Retrieved from http://niepodlegli.net/omarszu

[40] Kaczyński, Jarosław (2011, December 21). PiS murem za Macierewiczem. Rp.pl, kraj, polityka. Retrieved from http://www.rp.pl/artykul/738666,776952-Kierownictwo-PiS-przyjelouchwale-ws--Macierewicza.html

[41] Nisztor, Piotr \& Grażyna Zawadka (2012, January 4). MSW czyszczone z ludzi Schetyny. Onet.pl. Retrieved from http://wiadomosci.onet.pl/kraj/msw-czyszczone-z-ludzischetyny, 1,4988789, wiadomosc.html

[42] Biedroń, Robert \& Anna Wittenberg (2012, January 20). Osiągnęliśmy cel. Wszyscy o tym mówią. Salon Polityczny Trójki. Polskieradio.pl. Retrieved from http://www.polskieradio.pl/9/299/Artykul/521030,Osiagnelismy-cel-Wszyscy-o-tym-mowia

[43] Janicki, Mariusz \& Wiesław Władyka (2011, January 11). Premier i prezes przed wyborczym starciem. Donald Tusk, Jarosław Kaczyński. Ostatni taki pojedynek. Polityka.pl. Retrieved from http://www.polityka.pl/kraj/analizy/

1511746,1,premier-i-prezes-przed-wyborczym-starciem.read?backTo

=http://www.polityka.pl/kraj/wywiady/1520254,1,rozmowa-z-aleksandrem-hallem-ministrem-w-

rzadzie-mazowieckiego.read\#ixzz11QMGvKS5

[44] Kowalski, Radosław (2012, January 7). Palikot ostro skomentował zachowanie rzecznika rządu - Pawła Grasia. Wiadomosci24.pl. Retrieved from http://www.wiadomosci24.pl/artykul/palikot_ostro_skomentowal_zachowanie_rzecznika_rzadu_p awla_221958.html

[45] Nizinkiewicz, Jacek \& Stefan Niesiołowski (2012, January 15). Niesiołowski: w poniedziałek PiS rozpęta na nowo piekło smoleńskie. Onet.pl. Retrieved from 
http://wiadomosci.onet.pl/kraj/niesiolowski-w-poniedzialek-pis-rozpeta-na-nowopi,1,4998338, wiadomosc.html

[46] Dąbrowska, Anna \& Grzegorz Rzeczkowski (2010, February 11). PO walczy o głosy wsi. Platforma ludowa. Polityka.pl. Retrieved from http://www.polityka.pl/kraj

/analizy/1502551,1,po-walczy-o-glosy-wsi.read?

[47] Wittenberg, Anna (2012, January 30). Rafał Grupiński: Platforma nie jest bez grzechu. Polskieradio.pl. Retrieved from http://www.polskieradio.pl/9

/299/Artykul/527096,Rafal-Grupinski-Platforma-nie-jest-bez-grzechu

[48] Ujazdowski, Michał (2012, February 1). Ujazdowski: PO jest formacją antywolnościową. Onet.pl.

http://wiadomosci.onet.pl/kraj/ujazdowski-po-jest-formacjaantywolnosciowa, 1,5014131, wiadomosc.html

[49] Jaryczewski, Artur (2012, January 27). Politycy będą "patrzeć na ręce" prokuraturom. Polskieradio.pl. Salon Polityczny Trójki. Retrieved from http://www.polskieradio.pl/9/299/Artykul/525887,Politycy-beda-patrzec-na-rece -prokuraturom

[50] Anna Wittenberg \& Marek Sawicki (2012, January 18). Sawicki: politycy uprawiają nekrofilię na tragedii. Polskieradio.pl. Salon Polityczny Trójki. Retrieved from http://www.polskieradio.pl/9/299/Artykul/519515,Sawicki-politycy-uprawiaja-nekrofilie-natragedii

[51] Janicki, Mariusz \& Wawrzyniec Smoczyński (2011, April 5). Politycy idą między ludzi. Jak oni się mizdrzą!Polityk szary człowiek. Retrieved from http://www.polityka.pl/kraj/analizy/1514454,2,politycy-ida-miedzy-ludzi-jak-oni-sie-

mizdrza.read\#ixzz1lPjXvuha

[52] Kamińska, Agnieszka \& Mikołaj Dowgielewicz (2012, February 2). Polska nie może stać na mrozie i walić głową w mur. Polskieradio.pl. Retrieved from http://www.polskieradio.pl/

9/299/Artykul/529421,Polska-nie-moze-stac-na-mrozie-i-walic-glowa-w-mur

[53] Warzecha, Łukasz (2011, December 23). Polska drugiego obiegu. Rp.pl. Retrieved from http://www.rp.pl/artykul/777651-Polska-drugiego--obiegu.html

[54] Legutko, Piotr (2011, December 26). Do ostatniej krwi. Rp.pl. Retrieved from http://www.rp.pl/artykul/9157,779182-Podzielona-Polska-i-polityka---Legutko.html

[55] Umorzono postępowanie w sprawie znieważenia prezydenta przez polityka PiS. (2012, January 19). Onet.pl Retrieved from http://wiadomosci.onet.pl/kraj/umorzono-postepowanie-wsprawie-zniewazenia-prezyd, 1,5003135, wiadomosc.html

[56] Paradowska, Janina \& Grzegorz Schetyna (2011, November 29). Potrafię czekać. Polityka.pl. Retrieved from http://www.polityka.pl/kraj/wywiady/

1521592,1,janina-paradowska-rozmawia-z-grzegorzem-schetyna.read

[57] Wybranowski, Wojciech (2012, Januray 13). Prawo i Sprawiedliwość i przedwyborcza czystka. Rp.pl. Retrieved from http://www.rp.pl/artykul/791013.html

[58] Kurski: premier Tusk poniósł klęskę w sprawie paktu fiskalnego. (2012, January 31). Onet.pl

Retrieved from http://wiadomosci.onet.pl/kraj/kurski-premier-tusk-poniosl-kleske-w-sprawiepaktu,1,5013453, wiadomosc.html

[59] Jaworski, Kazimierz (2011, November 25). Solidarna Polska - trudna decyzja [Web blog post]. Kazimierzjaworski.pl. Retrieved from http://www.kazimierzjaworski.pl/?q=node/43

[60] Senyszyn, Joanna (2012, January 25). Senyszyn: Macierewicz powinien wypożyczyć Tu-154 $\mathrm{i}$ polecieć na spotkanie $\mathrm{z}$ brzozą. Blogi polityczne $w$ Onecie. Retrieved from http://wiadomosci.onet.pl/temat/katastrofa-smolenska/senyszyn-macierewicz-powinien-

wypozyczyc-tu-154-i-,1,5007589, wiadomosc.html

[61] SLD chce likwidacji Instytutu Pamięci Narodowej. (2012, January 16). Onet.pl. Retrieved from http://wiadomosci.onet.pl/kraj/sld-chce-likwidacji-instytutu-pamiecinarodowej,1,4998700, wiadomosc.html

[62] Rzeczkowski, Grzegorz (2011, November 8). Rozmowa: Socjolog o przyszłości Ziobry i Kaczyńskiego. Polityka.pl. Retrieved from http://www.polityka.pl/kraj/ 
wywiady/1521182,1,rozmowa-socjolog-o-przyszlosci-ziobry-i-kaczynskiego.read

[63] Solidarna Polska chce pojedynku z Palikotem. Zapowiadają odwet. (2012, January 31).

Onet.pl. Retrieved from http://wiadomosci.onet.pl/kraj/solidarna-polska-chce-pojedynku-zpalikotem-zapowi, 1,5013443, wiadomosc.html

[64] Komorowski podjął decyzję ws. szefa prokuratury wojskowej. Mularczyk: spektakl został przerwany (2012, January 31). Onet.pl. Retrieved from http://wiadomosci.onet.pl/kraj/komorowski-podjal-decyzje-ws-szefa-prokuratury-

woj, 1,5013692, wiadomosc.html

[65] Schetyna: Te zeznania potwierdzają, że były zbierane "haki" (2011, November 15). TVN24.pl. Retrieved from http://www.tvn24.pl/12690,1724183,0,1,schetyna-te-zeznaniapotwierdzaja--ze-byly-zbierane-haki,wiadomosc.html

[66] Niesiołowski: telewizja Trwam jest trucizną, źródłem kłamstwa i nienawiści. (2012, January 15). Onet.pl. Retrieved from http://wiadomosci.onet.pl/tylko-w-onecie/niesiolowski-telewizjatrwam-jest-trucizna-zrodlem, 1,4998622, wiadomosc.html

[67] Senyszyn, Joanna. (2012, January 23). ACTA- bachor polskiej prezydencji. [Web blog post]. Retrieved from http://senyszyn.blog.onet.pl/ACTA-BACHOR-POLSKIEJPREZYDENC,2,ID449425506,RS1,n

[68] Paradowska, Janina (2012, January 26). Totalny chaos! Rząd nie panuje nad sytuacją, a może... Wp.pl.sondaż polityczny. Retrieved from http://sondaz.

wp.pl/wid,14196520,wiadomosc.html?ticaid=1ea85\&_ticrsn=3

[69] Gabryel, Piotr (2012, January 13). Tusk poślizgnął się na jej "brakoróbstwie". Wp.pl. Retrieved from http://sondaz.wp.pl/kat,60878,wid,14156076, wiadomosc.html

[70] Olczyk, Eliza (2011, December 29). Tylko krach w Unii zmógłby Tuska. Rp.pl. Retrieved from http://www.rp.pl/artykul/782688.html

[71] Janina Paradowska (2011, March 15). Schetyna dla POLITYKI: Ucierpiały relacje z premierem. Polityka.pl. Retrieved from http://www.polityka.pl/kraj/

1514048,1 ,schetyna-dla-polityki-ucierpialy-relacje-z-premierem

[72] Raciborski, Jacek \& Grzegorz Rzeczkowski (2011, August 23). ROZMOWA: Socjolog o kryzysie SLD. Upadek lewicowego ducha. Polityka.pl. Retrieved from http://www.polityka.pl/kraj/wywiady/1518804,1,rozmowa-socjolog-o-kryzysie-

sld.read\#ixzz1lPTw6WRf

[73] Kamińska, Agnieszka (2012, January 25). Poseł PiS: w listopadzie premier przejrzał na oczy.

Polskieradio.pl. Retrieved from http://www.polskieradio.pl/9/299/Artykul/524295,Posel-PiS-wlistopadzie-premier-przejrzal-na-oczy

[74] Wojna o urlopy - Kaczyński miał więcej wolnego niż Tusk. (2012, January 18). Wiadomosci.pl. Retrieved from http://wiadomosci.wp.pl/title,Wojna-o-urlopy-Kaczynski-mialwiecej-wolnego-niz-Tusk, wid,14177343, wiadomosc.html

[75] Wojna prokuratur - wojskowej z generalną (2012, January 9). Gazetawyborcza.pl. Retrieved from http://wyborcza.pl/1,75478,10934739,

Wojna_prokuratur__wojskowej_z_generalna.html

[76] Palikot, Janusz (2007, October 27). Wojna z biurokracją. [Web blog post]. Retrieved from http://palikot.blog.onet.pl/1,CT44431,index.html

[77] Kurski: zaskoczyła nas decyzja PiS, wpadliśmy w czarną dziurę. (2011, December 28). Wiadomosci.pl. Retrieved from http://wiadomosci.onet.pl/kraj/kurski-zaskoczyla-nas-decyzja-piswpadlismy-w-czar,1,4983339, wiadomosc.html

[78] Paradowska, Janina \& Malwina Dziedzic (2011, June 6). Obóz Kaczyńskiego. Kto w nim jest? Wszyscy ludzie prezesa. Polityka.pl. Retrieved from http://www.polityka.pl/kraj/analizy/1516368,2,oboz-kaczynskiego-kto-w-nimjest.read\#ixzz11Q3SOavh

[79] Czarnecki obiecuje: wysadzimy to badziewie w powietrze. (2012, January 27). Onet.pl. Retrieved from http://wiadomosci.onet.pl/tylko-w-onecie/czarnecki-obiecuje-wysadzimy-tobadziewie-w-powiet, 1,5010253, wiadomosc.html 
[80] Władyka, Wiesław \& Paweł Machcewicz (2011, April 15). WYWIAD: Jak Smoleńsk zapisze się w historii. Lęk i mit. Polityka.pl. Retrieved from http://www.polityka.pl/kraj/ wywiady/ 1514588,1,wywiad-jak-smolensk-zapisze-sie-w-historii.read\#ixzz1 hqEpT0wW

[81] Podgórska, Joanna \& Barbara Labuda (2011, April 6). Ministerka świeckości. Polityka.pl. Retrieved from http://www.polityka.pl/kraj/ludzie/1514386,1,rozmowa-z-barbaralabuda.read\#ixzz1hqL0lw3W

[82] Paradowska, Janina \& Grzegorz Schetyna (2011, March 24). Drugi PO. Polityka.pl. Retrieved fromhttp://www.polityka.pl/kraj/wywiady/1513934,1,wywiad-marszalek-sejmu-grzegorz-

schetyna-dla-polityki.read\#ixzz1hqYeLCSk

[83] Baczyński, Jerzy \& Janina Paradowska (2011, March 7). Po romansie małżeństwo. Polityka.pl. Retrieved from http://www.polityka.pl/kraj/wywiady/

1513588,1,rozmowa-z-premierem-donaldem-tuskiem.read\#ixzz1hqi6G0qz

[84] Łazarewicz, Cezary \& Paweł Borecki (2011, February 24). Polska się laicyzuje. Ile Kościoła, ile państwa i Państwa? Polityka.pl. Retrieved from http://www.polityka.

pl/kraj/wywiady/1513442,1,wywiad-polska-sie-laicyzuje.read\#ixzzl hqzlHrfw

[85] Paradowska, Janina \& Donald Tusk (2010, December 29). Nauczyłem się czekać. Polityka.pl. Retrieved from http://www.polityka.pl/kraj/wywiady/

1511600,1,wywiad-janina-paradowska-pyta-premiera-donalda-tuska.read\#ixzz1hr8CXA59

[86] Jurek, Marek \& Katarzyna Karaś (2011, December 27). Ziobro mógłby stanąć na czele ruchu prawicowego. Salon Polityczny Trójki. Retrieved from http://www.polskieradio.pl/9/299/Artykul/506634,Ziobro-moglby-stanac-na-czele -ruchu-prawicowego

[87] Grzesiowski, Krzysztof (2011, December 12). Rozmowa z Leszkiem Millerem. PolskieRadio.pl. Retrieved from http://www.polskieradio.pl/13/53/Artykul/

497645,Rozmowa-z-Leszkiem-Millerem

[88] Paradowska, Janina \& Aleksander Kwaśniewski (2011, November 8). Palikot jest do ogrania. Polityka.pl. Retrieved from http://www.polityka.pl/kraj/wywiady/1520914,1,paradowska-ikwasniewski-rozmawiaja-o-lewicy-i-tusku.read\#ixzz1hmVV6reF

[89] Hall, Aleksander \& Wiesław Władyka (2011, October 23). Dobrze nam się wydarzyło. Polityka.pl. Retrieved from http://www.polityka.pl/kraj/wywiady/1520254,1,rozmowa-zaleksandrem-hallem-ministrem-w-rzadzie-mazowieckiego.read\#ixzz1hmfhFIkz

[90] Kowal, Paweł (2011, February 14). Chcemy nadać polityce powiew młodości. Salon Polityczny Trójki. Polskieradio.pl. Retrieved from http://www.polskieradio.pl

19/299/Artykul/312475,Chcemy-nadac-polityce-powiew-mlodosci

[91] Paradowska, Janina \& Joanną Kluzik-Rostkowska (2011, May 31). Sprawa honoru. Polityka.pl. Retrieved from http://www.polityka.pl/kraj/wywiady/

1516170,1,rozmowa-z-joanna-kluzik-rostkowska-szefowa-pjn.read\#ixzz1hmlDaw6h

[92] Rzeczkowski, Grzegorz \& Piotr Stasiak (2011, May 24). Wywiad społecznościowy z prezydentem. Prezydent Bronisław Komorowski dla POLITYKA.PL. Polityka.pl. Retrieved from http://www.polityka.pl/kraj/wywiady

/1516116,1,wywiad-spolecznosciowy-z-prezydentem.read\#ixzz1yGuDHZKZ

[93] Rzeczkowski, Grzegorz \& Edmund Wnuk-Lipiński (2011, April 16). Robespierre Kaczyński. Polityka.pl. Retrieved from http://www.polityka.pl/kraj/wywiady/1514976,1,rozmowa-socjolog-ostrategii-jaroslawa-kaczynskiego.read\#ixzz1hmqsWqZG

[94] Rzeczkowski, Grzegorz \& Jacek Wasilewski (2011, May 16). Socjolog o PO i premierze: wkurzają mnie. Polityka.pl. Retrieved from http://www.polityka.pl

/kraj/wywiady/1515890,1,socjolog-o-po-i-premierze-wkurzaja-mnie.read\#ixzz1hmu7oQt

[95] Miller, Leszek \& Agnieszka Burzyńska (2011, October 22). Leszek Miller: Polityk uwodzi wyborców, żeby otworzyli ramiona i zamknęli oczy. Rmf24.pl. Retrieved from http://www.rmf24.pl/tylko-w-rmf24/wywiady/przesluchanie/news-leszek-miller-polityk-uwodziwyborcow-zeby-otworzyli,nId,369279 
[96] Piasecki, Konrad \& Włodzimierz Cimoszewicz (2011, December 20). Włodzimierz Cimoszewicz: Przestrzegałbym przed padaniem w ramiona Palikota. Rmf24.pl. Retrieved from http://www.rmf24.pl/tylko-w-rmf24/wywiady/kontrwywiad/news-wlodzimierz-cimoszewiczprzestrzegalbym-sld-przed-padaniem,nId,422692

[97] Burzyńska, Agnieszka \& Zbigniew Ziobro (2011, November 26). Ziobro: Państwo sobie odpuściło, w PZPN rozwinęła się gangrena, którą trudno zwalczyć. Rmf24.pl. Retrieved from http://www.rmf24.pl/tylko-w-rmf24/wywiady/przesluchanie/news-ziobro-panstwo-sobie-

odpuscilo-w-pzpn-rozwinela-sie,nId,388763

[98] Piasecki, Konrad \& Mariusz Kamiński (2011, November 23). Mariusz Kamiński: Poprzemy jedną $\mathrm{z}$ reform Tuska, reszta jest bulwersująca. Rmf24.pl. Retrieved from http://www.rmf24.pl/tylko-w-rmf24/wywiady/kontrwywiad/news-mariusz-kaminski-poprzemyjedna-z-reform-tuska-reszta-jest,nId,388034

[99] Piasecki, Konrad \& Marek Belka (2011, November 16). Marek Belka: Widzę u Rostowskiego i Tuska chęć do zaciskania pasa. Rmf24.pl. Retrieved from http://www.rmf24.pl/tylko-w$\mathrm{rmf} 24 /$ wywiady/kontrwywiad/news-marek-belka-widze-u-rostowskiego-i-tuska-chec-dozaciskania,nId,386549

[100] Burzyńska, Agnieszka \& Tadeusz Cymański (2011, October 29). Cymański: Prezes nie potrzbuje pochlebców, kolesie nie maja racji. Rmf24.pl. Retrieved from http://www.rmf24.pl/fakty/polska/news-cymanski-prezes-nie-potrzebuje-pochlebcow-kolesie-niemaja,nId,382941

[101] Piasecki, Konrad \& Zbigniew Ziobro (2011, October 25). Zbigniew Ziobro: Wielu wątpi, czy PiS jest jeszcze w stanie wygrywać. Rmf24.pl. Retrieved from http://www.rmf24.pl/tylko-wrmf24/wywiady/kontrwywiad/news-zbigniew-ziobro-wielu-watpi-czy-pis-jest-jeszcze-w-

stanie,nId,369799

[102] Piasecki, Konrad \& Tomasz Nałęcz (2011, October 21). Nałęcz: Prezydent życzy zgody Tuskowi i Schetynie. Rmf24.pl. Retrieved from http://www.rmf24.pl/fakty/polska/news-naleczprezydent-zyczy-zgody-tuskowi-i-schetynie,nId,366435

[103] Piasecki, Konrad \& Leszek Miller (2011, October 14). Leszek Miller: Tusk sam założył sobie koronę, jestem zachwycony. Rmf24.pl. Retrieved from http://www.rmf24.pl/tylko-wrmf24/wywiady/kontrwywiad/news-leszek-miller-tusk-sam-zalozyl-sobie-korone-

jestem,nId,365091

[104] Piasecki, Konrad \& Jarosław Gowin (2011, October 13). Gowin: Schetyna wicepremierem, Tusk rozkłada siły, pozycjonuje armię. Rmf24.pl. Retrieved from http://www.rmf24.pl/tylko-wrmf24/wywiady/kontrwywiad/news-gowin-schetyna-wicepremierem-tusk-rozklada-

sily,nId,364882

[105] Piasecki, Konrad \& Lech Wałęsa (2011, September 30). Wałęsa: Nawet jeżeli PiS wygra wybory i tak nie będzie rządzić. Rmf24.pl. Retrieved from http://www.rmf24.pl/tylko-w$\mathrm{rmf} 24 /$ wywiady/kontrwywiad/news-walesa-nawet-jezeli-pis-wygra-wybory-i-tak-nie-

bedzie,nId,362422 [105] I

[106] Piasecki, Konrad \& Wojciech Olejniczak (2011, October 20). Olejniczak: SLD jest dziś na samym dnie. Rmf24.pl. Retrieved from http://www.rmf24.pl/fakty/polska/news-olejniczak-sld-jestdzis-na-samym-dnie,nId,366154

[107] Wojciechowski: PiS sześć razy przegrał, ale i tak za wszystko odpowiada. (2011, December 27). Onet.pl. Retrieved from http://wiadomosci.onet.pl/tylko-w-onecie/wojciechowski-pis-szescrazy-przegral-ale-i-tak-za, 1,4982906, wiadomosc.html

[108] Jakubiak, Elżbieta (2011, February 2). Uchronić Polaków przed bitwą PiS - PO. Salon Polityczny Trójki. Polskieradio.pl. $\quad$ Retrieved from http://www.polskieradio.pl/9/299/Artykul/305670,Uchronic-Polakow-przed-bitwa-PiS-PO 